\title{
A Case of Lymphoepithelial Cyst of the Pancreas
}

\author{
NAOFUMI ERIGUCHI, SHIGEAKI AOYAGI, KOJI OKUDA, HIROYASU IMAYAMA, \\ TSUYOSHI TAMAE, SHUICHI FUKUDA, MAHIRO IMAMURA, SHIGERU HAMADA, \\ SHINJI SATO, KOTARO HASHINO AND ATSUO JIMI*
}

Departments of Surgery and Pathology*, Kurume University School of Medicine, Kurume 830-0011, Japan

\begin{abstract}
Summary: We report a relatively rare case of lymphoepithelial cyst of the pancreas. The patient, a 43-year-old man with no subjective symptoms, was found to have a pancreatic tumor during a physical examination. Based on the ultrasonographic and abdominal computed tomographic findings, a pancreatic cystic tumor was diagnosed. Endoscopic retrograde pancreatography showed a normal duct system. Enucleation was easily performed. Macroscopically, the cyst resembled an atheroma. Histopathologic examination disclosed lymphoepithelial cyst of the pancreas.
\end{abstract}

Key words lymphoepithelial cyst, pancreatic cyst, surgery

\section{INTRODUCTION}

Lymphoepithelial cysts of the pancreas (LECP) are rare lesions. They are squamous cell-lined cysts closely associated with the pancreas, filled with keratinized material and surrounded by lymphoid tissue [1]. To our knowledge there have been 32 reported cases in the English literature. We describe a case of lymphoepithelial cyst located in the head of the pancreas and review the literature.

\section{CASE REPORT}

A 43-year-old man was referred to our hospital, since he was found to have a cystic lesion in the head of the pancreas by an abdominal ultrasonography (US). His family and past medical history was unremarkable. Laboratory data on admission were about normal, including tumor markers such as carcinoembryonic antigen (CEA) or carbohydrate antigen (CA19-9). On US, the mass was found to be cystic (Fig. 1a). Computed tomography (CT) showed a hypodense lesion in the pancreatic head without invasive signs to the adjacent tissues (Fig. 1b). Endoscopic retrograde cholangiopancreatography showed a normal duct system without any abnormal findings. Abdominal angiography revealed no tumor stain and no vessel encasement. Based on these findings, we diagnosed this lesion as a cystic tumor of the pancreas.

At laparotomy a $7.0 \times 6.5 \times 6.0 \mathrm{~cm}$ mass was found at the pancreatic head. It was encapsulated and originated from the head of the pancreas. The mass was easily dissected out of its pancreatic bed without blood loss or injury to the pancreas. Macroscopically, the mass contained a cheesy, white material. The cut surface of the resected specimens revealed a thinwalled unilocular cyst which was filled with whitish pasty material. Histologically, the cyst was filled with keratin and lined by mature keratinizing squamous epithelium (Fig. 1c). The epithelium was supported by a small layer of lymphoid tissue without lymph follicle (Fig. 1d). Teratoid elements such as skin appendages or mesenchymal tissue were lacking.

\section{DISCUSSION}

Lymphoepithelial cyst is a cystic lesion lined by mature keratinizing squamous epithelium supported by distinct lymphoid tissue. Recently, it has been suggested that it arises from a benign epithelial inclusion in a parapancreatic lymph node [2], but in another report lymphoepithelial cysts are considered 


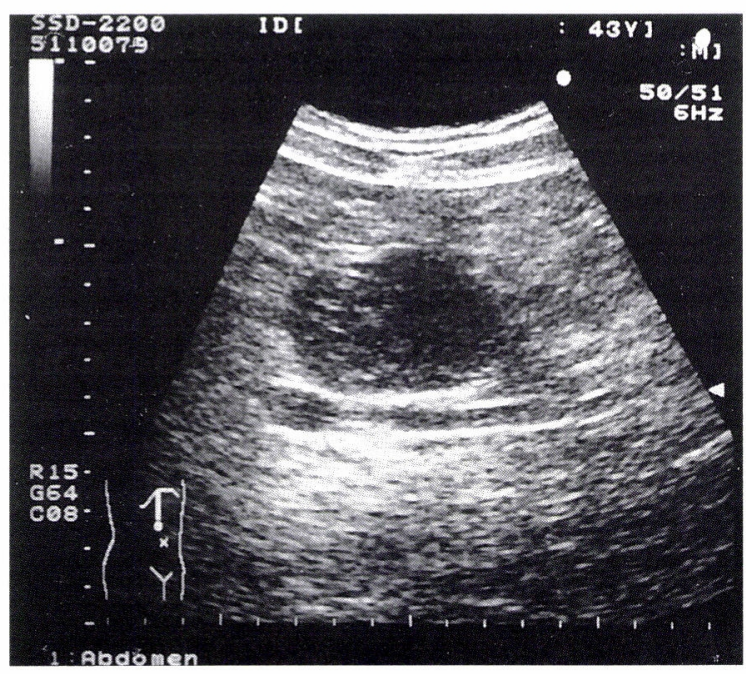

a

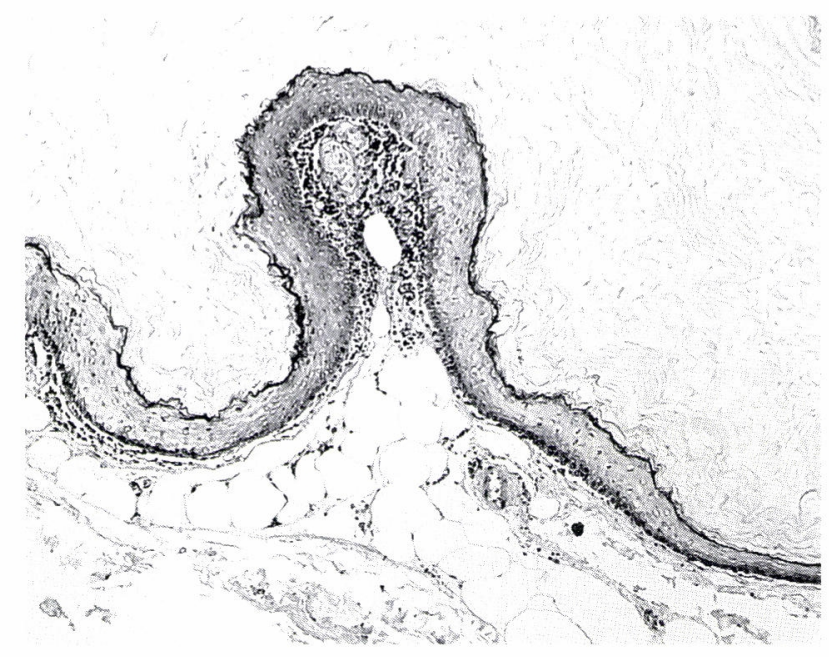

C

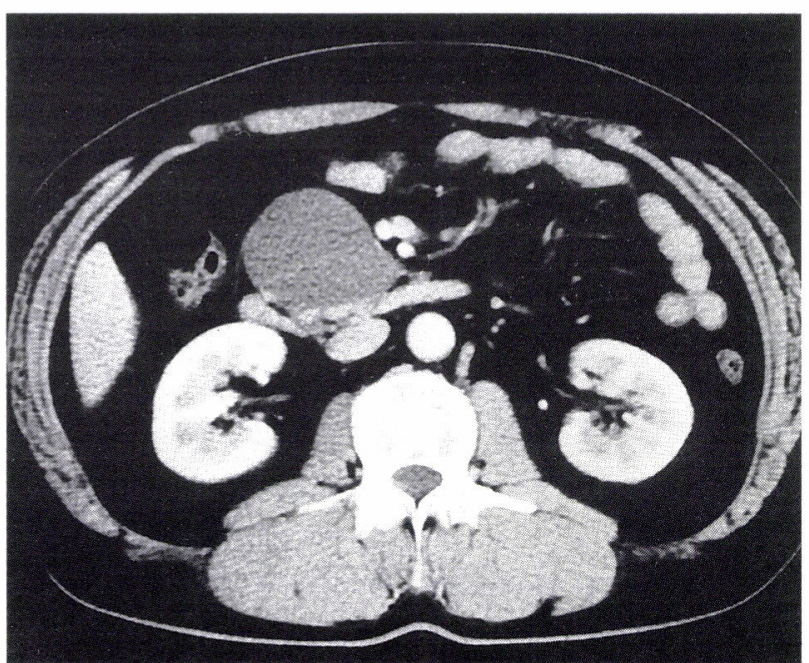

b

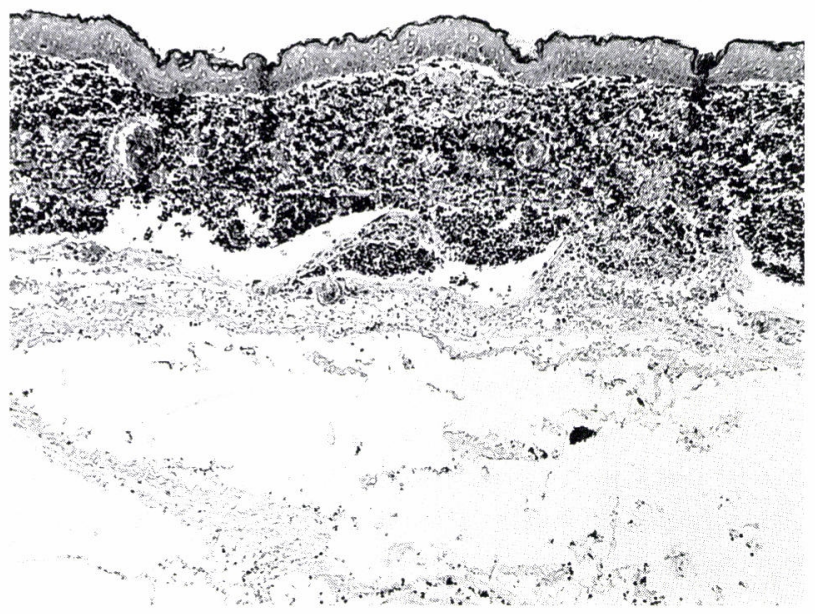

d

Fig. 1. a: Abdominal ultrasonographic finding revealed a hypoechoic lesion located in the head of the pancreas. b: Contrast enhanced computed tomographic scan showed a hypodense lesion in the head of the pancreas. c: Histopathological findings of the cyst. The cyst wall is lined by mature keratinizing squamous epithelium. $(\mathrm{H} \& \mathrm{E} \times 50)$

d: Dense lymphoid tissue is present in the cyst wall. Keratinous debris is within the cyst. $(\mathrm{H} \& \mathrm{E} \times 50)$

to be dermoid cysts of the pancreas [3]. The pancreatic cyst lined by squamous epithelium with surrounding lymphoid tissue was described in 1985 by Luchtrath and Schriefers [4]. The term lymphoepithelial cyst was coined by Truong et al. [5], when they reported the second case in 1987.

Since that time 30 more case reports have been published describing similar pathology (Table 1) [2,4-20]. Males are more often affected, with only three cases involving females. Patients range in age from 35 to 74 years (mean 56 years). The cyst is often asymptomatic, with cases discovered incidentally at autopsy or unrelated surgery.

Clinically, LECP presents with no specific symptoms: abdominal pain was present in 13 cases, diarrhea in 2 cases, and weight loss in 1 , whereas 13 cases were incidentally found during workup and 2 at autopsy. The lesion was located in the head of the pancreas in 13 patients, the body in 10, and the tail in 7. The size of the lesion ranged from 2.0 to $13.0 \mathrm{~cm}$ 
TABLE 1.

Reported cases of lymphoepithelial cyst of the pancreas

\begin{tabular}{|c|c|c|c|c|c|c|c|c|}
\hline No & Author & & Age / Sex & Symptoms & Diagnostic studies & Location & Size $(\mathrm{cm})$ / Shape & Treatment \\
\hline 1 & Luchtrath $^{4}$ & '85 & $36 / \mathrm{M}$ & Weight loss & CT, US & $\mathrm{Pbt}$ & 9.0/ multilocular & Excision \\
\hline 2 & Truong $^{5}$ & '87 & $35 / \mathrm{M}$ & Diarrhoea, pain & CT, US & $\mathrm{Pb}$ & $6.0 /$ unilocular & Excision \\
\hline 3 & Mockli $^{6}$ & '90 & $72 / \mathrm{M}$ & Dyspnea & Autopsy & $\mathrm{Pt}$ & 4.0/ multilocular & I \\
\hline 4 & Yamamoto $^{8}$ & '90 & $64 / \mathrm{M}$ & None & US, EUS, CT, MRI & $\mathrm{Pb}$ & 4.0/ bilocular & Excision \\
\hline 5 & Mitchell $^{8}$ & '90 & $42 / \mathrm{M}$ & Abdominal pain & CT, ERCP, FNA & $\mathrm{Ph}$ & $6.0 /$ multilocular & Excision \\
\hline 6 & Hisaoka $^{8}$ & '91 & $65 / \mathrm{M}$ & None & CT, US, EUS & $\mathrm{Pb}$ & $5.0 /$ multilocular & DP \\
\hline 7 & Ramsden $^{8}$ & '91 & $73 / \mathrm{M}$ & None & Autopsy & $\mathrm{Pb}$ & 2.0/ unilocular & I \\
\hline 8 & Kaiserling ${ }^{8}$ & '91 & $53 / \mathrm{M}$ & Fatigue & US, CT, FNA & $\mathrm{Pt}$ & $8.0 /$ multilocular & $\mathrm{DP}$ \\
\hline 9 & DiCorato $^{8}$ & '92 & $43 / \mathrm{M}$ & None & CT & $\mathrm{Pt}$ & 3.0/ unilocular & DP \\
\hline 10 & Bastens $^{8}$ & '92 & $66 / \mathrm{F}$ & Abdominal pain & US, CT, ERCP & $\mathrm{Ph}$ & 4.0/ unilocular & Excision \\
\hline 11 & Cappellari $^{8}$ & '93 & $44 / \mathrm{M}$ & Abdominal pain & CT, FNA & $\mathrm{Ph}$ & $6.0 /$ bilocular & Excision \\
\hline 12 & Hausegger $^{8}$ & '93 & $66 / \mathrm{M}$ & None & CT, ERCP & $\mathrm{Pt}$ & 5.0/ unilocular & Excision \\
\hline 13 & De Lorenzi ${ }^{8}$ & '93 & 59/M & None & CT, MRI, US & $\mathrm{Ph}$ & $6.5 /$ multilocular & Excision \\
\hline 14 & Goodman $^{8}$ & '94 & $68 / \mathrm{M}$ & Abdominal pain & UGI, CT, ERCP & $\mathrm{Pb}$ & 13.0/ unilocular & Excision \\
\hline 15 & Ueno $^{7}$ & '94 & 69/M & Abdominal pain & CT, US, EUS & $\mathrm{Pb}$ & 3.0/ unilocular & Unknown \\
\hline 16 & Ueno & '94 & $58 / \mathrm{M}$ & Abdominal pain & CT, US, MRI & $\mathrm{Pb}$ & $2.0 /$ multilocular & Unknown \\
\hline 17 & Fitko $^{8}$ & '94 & $60 / \mathrm{M}$ & Abdominal pain & US, CT & $\mathrm{Pb}$ & 4.5/ unilocular & Excision \\
\hline 18 & Rino $^{9}$ & '95 & $58 / \mathrm{M}$ & None & US, CT, ERCP, FNA & Phb & $6.1 /$ multilocular & Excision \\
\hline 19 & $\operatorname{Koga}^{10}$ & '95 & $62 / \mathrm{M}$ & None & US, CT & $\mathrm{Ph}$ & $6.0 /$ multilocular & PD \\
\hline 20 & Koga & '95 & $56 / \mathrm{M}$ & None & US, CT & $\mathrm{Ph}$ & $3.5 /$ multilocular & Excision \\
\hline 21 & Katz $^{11}$ & '95 & $42 / \mathrm{F}$ & Abdominal pain & CT, ERCP & $\mathrm{Ph}$ & 5.0/ multilocular & Excision \\
\hline 22 & Iacono $^{12}$ & '96 & $56 / \mathrm{M}$ & Abdominal pain & US, CT & $\mathrm{Ph}$ & 3.5/ unilocular & Excision \\
\hline 23 & Iacono & '96 & $47 / \mathrm{M}$ & None & $\mathrm{CT}, \mathrm{US}$ & $\mathrm{Pb}$ & 7.0/ unilocular & Excision \\
\hline 24 & Schinke-Nickl ${ }^{13}$ & '96 & $59 / \mathrm{M}$ & Diarrhoea, pain & US, ERCP, CT, MRI & $\mathrm{Ph}$ & 8.0/ multilocular & Unknown \\
\hline 25 & $\mathrm{Gafa}^{14}$ & '97 & $57 / \mathrm{M}$ & Abdominal pain & US & $\mathrm{Ph}$ & 2.5/ unilocular & Excision \\
\hline 26 & Kazumori $^{15}$ & '97 & $48 / \mathrm{M}$ & General fatigue & CT, MRI, EUS, ERP & $\mathrm{Pt}$ & 2.5/multilocular & $\mathrm{DP}$ \\
\hline 27 & Furukura $^{16}$ & '98 & $70 / \mathrm{M}$ & Diarrhea & $\mathrm{CT}, \mathrm{MRI}$ & $\mathrm{Pt}$ & 10.0/ unilocular & Unknown \\
\hline 28 & Furukura & '98 & $74 / \mathrm{M}$ & None & CT, MRI, US & $\mathrm{Ph}$ & 4.0/ multilocular & Unknown \\
\hline 29 & Tateyama $^{17}$ & '98 & $59 / \mathrm{M}$ & None & US, CT & $\mathrm{Pt}$ & 5.0/ multilocular & PR \\
\hline 30 & Strapko ${ }^{18}$ & '98 & $42 / \mathrm{F}$ & Abdominal pain & $\mathrm{CT}, \mathrm{US}$ & $\mathrm{Pb}$ & 4.0/ multilocular & Excision \\
\hline 31 & Chan $^{19}$ & '98 & $47 / \mathrm{M}$ & Back pain & US, CT, FNA & $\mathrm{Ph}$ & $5.0 /$ multilocular & Excision \\
\hline 32 & Bolis $^{20}$ & '98 & 64/M & G-I complaints & FNA, EUS, CT & Phb & 5.5/ unknown & Operation $(-)$ \\
\hline 33 & Present case & '99 & $43 / \mathrm{M}$ & None & CT, US, MRI & $\mathrm{Ph}$ & 6.0/ unilocular & Excision \\
\hline
\end{tabular}

DP: distal pancreatectomy; PD: pancreatoduodenectomy; PR: partial resection

CT: computed tomography; US: ultrasonography; EUS: endoscopic ultrasonography

ERCP: endoscopic retrograde cholangiopancreatography; FNA: fine needle aspiration

MRI: magnetic resonance imaging

Pbt: pancreatic body and tail; $\mathrm{Pb}$ : pancreatic body; Pt: pancreatic tail; $\mathrm{Ph}$ : pancreatic head

Phb: pancreatic head and body

in maximal diameter. Macroscopically, the cysts contained keratinous debris, and were multilocular in 16 cases and unilocular in 13 , as in our case.

Surgical therapy is the only way of guaranteeing resolution. The surgical treatment consisted of enucleation or enucleoresection in 19 cases, as in our case, and distal pancreatectomy in 4 cases, and pancreatoduodenectomy in only one case. Enucleation of the tumor is the best procedure if there are no tenacious adhesion to the pancreatic tissue and no risk of laceration with consequent hemorrhage or fistula.

LECP should be considered in the differential diagnosis of cystic lesions of the pancreas. Preoperative diagnosis is difficult. According to several reports $[9,19]$, percutaneous fine needle aspiration biopsy (PFNAB) may be helpful in reaching a correct diagnosis of LECP. But PFNAB sometimes failed to provide a diagnosis [8].

The histogenesis of LECP is not yet clear and 
many hypotheses have been reported: 1) Squamous metaplasia of an obstructed and dilated pancreatic duct which subsequently protrudes into a peripancreatic lymph node [2,5]. 2) Fusion of a peripancreatic lymph node with the pancreatic parenchyma during ontogeny [6]. 3) Development from misplaced branchial cleft tissue fused with the pancreas during embryogenesis $[1,8]$, or from a lymph node that contains epithelial inclusion or ectopic pancreas [5].

In conclusion, LECP is a relatively rare benign lesion that requires a great effort to be diagnosed preoperatively. There are no radiological or serological specific findings to distinguish LECP from other cystic pancreatic lesions. The surgical excision of the lesion seems to be the appropriate therapy in symptomatic patients or when a precise preoperative diagnosis is not achieved, whereas in asymptomatic patients with a morphologic preoperative diagnosis, the cyst may be left in place, and the patients clinically followed up [12]. As squamous cell carcinoma or mucoepidermoid carcinoma sometimes arise from the epithelium of lateral neck branchial cleft cysts, the possibility of associated malignancy should be kept in mind [7].

\section{REFERENCES}

1. Solcia E, Capella C, and Kloppel G. Tumors of the pancreas. In: Atlas of Tumor Pathology, 3rd series. Fasc.20, ed. Rosai J, Armed Forces Institute of Pathology, Washington, D.C., pp 220-223, 1997.

2. Hisaoka M, Haratake J, Horie A, Yasunami Y, and Kimura T. Lymphoepithelial cyst of the pancreas in a 65year-old man. Hum Pathol 1997; 22:924-926.

3. Vermeulen BJM, Widgren S, Gur V, Meyer P, Iselin C et al. Dermoid cyst of the pancreas. Gasrtoent Clin Biol 1990; 14:1023-1025.

4. Luchtrath H, and Schriefers KH. Pankreaszyste unter dem Bild einer sogenannten brachiogenen Zyste. Der Pathologe 1985; 6:217-219.

5. Truong LD, Rangdaeng S, and Jordan PH Jr. Lymphoepithelial cyst of the pancreas. Am J Surg Pathol 1987; 11:899-903.

6. Mockli GC, and Stein RM. Cystic lymphoepithelial lesion of the pancreas. Arch Pathol Lab Med 1990; 114:885-887.

7. Ueno S, Muranaka T, Maekawa S, Masuda Y, Ro T et al. Radiographic feature in lymphoepithelial cyst of the pancreas. Abdom Imaging 1994; 19:232-234.

8. Fitko R, Kampmeier PA, Batti FH, Benjyoya RA, and Rao SM. Lymphoepithelial cyst of the pancreas with sebaceous differentiation. Int J Pancreatol 1994; 15:145147.

9. Rino Y, Morohoshi T, Funo K, Imada T, Yamamoto Y et al. Lymphoepithelial cyst of the pancreas: a preoperatively diagnosed case based on an aspiration biopsy. Surg Today 1995; 25:1043-1046.

10. Koga H, Takayasu K, Mukai K, Muramatsu Y, Mizoguchi Y et al. CT of lymphoepithelial cysts of the pancreas. J Comput Assist Tomogr 1995; 19:221-224.

11. Katz DS, Scatorchia GM, Wojtwycz AR, and Botash RJ. Lymphoepithelial cyst of the pancreatic head. Am J Radiol 1995; 165:489.

12. Iacono C, Cracco N, Zamboni G, Bernardello F, Zicari $\mathbf{M}$ et al. Lymphoepithelial cyst of the pancreas. Int $\mathbf{J}$ Pancreatol 1996; 19:71-76.

13. Schinke-Nickl DA, and Muller MF. Case report: lymphoepithelial cyst of the pancreas. Br J Radiol 1996; 69:876-878.

14. Gafa R, Grandi E, and Cavazzini L. Lymphoepithelial cyst of the pancreas. J Clin Pathol 1997; 50:794-795.

15. Kazumori H, Sizuku T, Ueki T, Uchida $Y$, and Yamamoto S. Lymphoepithelial cyst of the pancreas. J Gastroenterol 1997; 32:700-703.

16. Fukukura Y, Inoue H, Miyazono N, Kajiya Y, Fujiyoshi $F$ et al. Lymphoepithelial cysts of the pancreas: demonstration of lipid component using CT and MRI. J Comput Assist Tomogr 1998; 22:311-313.

17. Tateyama H, Tada T, Murase T, Fujitake S, and Eimoto T. Lymphoepithelial cyst and epidermoid cyst of the accessory spleen in the pancreas. Mod Pathol 1998; 11:1171-1177.

18. Strapko A, Botash RJ, Murthy UK, and Landas SK. Lymphoepithelial cyst of the pancreas, a case report and review of the literature. Dig Dis Sci 1998; 43:870-874.

19. Chan SP, Hatton CW, and Falk GL. Lymphoepithelial cyst of the pancreas: serum markers do not help. J Hep Bil Pancr Surg 1998; 11:121-124.

20. Bolis GB, Farabi $R$, Liberati $F$, and Maccio $T$. Lymphoepithelial cyst of the pancreas. Report of a case diagnosed by fine needle aspiration biopsy. Acta Cytol 1998; 42:384-386. 